\title{
Spatial Linkages in Listed Property Returns in Tranquil and Distressed Periods
}

\author{
BING ZHU* AND STANIMIRA MILCHEVA**
}

\begin{abstract}
This study uses a dynamic spatial panel model to assess the degree of cross-country co-movement of the returns of listed property companies caused by economic, financial, and geographic closeness. We find that the asset-side exposure of banks best captures the co-movements in returns and presents a channel of credit risk transmission across countries. During the global financial crisis, asset-side bank exposure and FDI linkages contribute to a significant increase in the comovement of the returns of listed property companies through which liquidity and credit risk shocks may be transmitted to asset prices internationally.
\end{abstract}

Keywords: Listed property company returns, International bank flows, Dynamic spatial panel model, Financial and geographic integration.

JEL Classifications: C23, G15, F36, R3

*University of Regensburg, IRE|BS, bing.zhu@irebs.de** University of Reading, Henley Business School, s.milcheva@ reading.ac.uk 


\section{Introduction}

In the aftermath of the global financial crisis (GFC) international investors became more concerned about the diversification benefits from investing in real estate internationally. Indeed, the GFC originated in the US real estate market and spread across the globe, affecting other national real estate markets and their economies. The crisis triggered a systemic risk component affecting asset returns across the world, undermining the diversification benefits of a global asset portfolio. Since real estate is characterized as being more heterogeneous and illiquid than stocks or bonds, thus depending more especially on asset-specific or local risk factors and less concerned with global market volatilities, it would be important to study the channels and the degree of the spatial comovements in real estate returns across different countries accounting for financial market exposure and economic linkages. We look, in particular, at property returns of listed real estate companies, since those returns are known to mirror both stock market and real estate fluctuations. Moreover, by investing in listed property companies, investors can mitigate problems related to the real estate illiquidity. This suggests that there is more scope for cross-country co-movements across this asset class than is observed for direct property. Return spillovers driven by financial market integration, on the one hand, are more probable across more liquid assets rather than across direct real estate. On the other hand, international listed property returns may correlate through different channels than equity returns, such as the credit channel and the global banking channel. Since the underlying asset class is real estate, which is known to be more capital intensive than other types of assets, listed property companies may face a funding shortage and show stronger co-movement with markets to which they are financially more exposed.

This study investigates the spatial linkages between listed property company returns in 14 countries using diverse measures of spatial proximity and distinguishing between the periods before and during the GFC. Risk-hedging through global diversification can be seriously affected by countryspecific shocks: if specific financial, economic, or geographic linkages exist between the countries, the cross-country correlation between returns increases. There are different mechanisms for transmitting variations in listed property company returns in one region when compared to returns in other regions. The concept developed in spatial econometrics is to capture the impact of a shock at a specific point in space on another place (Haining, 2003). Most of the existing research has assessed international stock market co-movements and has focused on the degree of dependence 
across markets (e.g. Karolyi and Stulz, 1996; Asgharian and Bengtsson, 2006; Asgharian and Nossman, 2011; Milcheva, 2013), but little research has been conducted on the channels connecting the asset markets. The most common spatial dependence widely studied in the literature is through geographic proximity (Fingleton, 2001, 2008). We add to the ongoing research on spatial linkages across property company returns by assessing a wide set of measures of financial and economic integration next to economic proximity, looking at their performance at different points in the economic cycle. Zhu, Fuess, and Rottke (2013) argue that geographic closeness is important for explaining housing return and volatility co-movements. However, economic proximity presents an additional source of property co-variations. Milcheva and Zhu (2015) find that bank integration can better capture international house price co-movements than other measures of economic integration. Therefore, we include measures such as bank asset-side exposure, bank liability-side exposure, bilateral foreign direct investment (FDI), bilateral trade, interest rate convergence, exchange rate convergence, inflation convergence and geographic proximity. It is important to account for this measure of financial integration since the international banking system is becoming a more important conduit for the transfer of capital across countries, as has been shown by the dramatic increase in international bank foreign claims in the last 20 years prior to the crisis (McGuire and Tarashev, 2007). Countries with high levels of bank balance-sheet foreign exposure would show higher interdependence in their asset markets.

We estimate a dynamic spatial panel model allowing for feedback effects. Furthermore, we control for differences in the spatial co-movement in normal and distressed periods and try to identify which are the most important linkages that capture the return co-variations across countries in the different subperiods. We can show that bank asset-side exposure best explains the co-movements in returns that could present a credit risk channel. Other important drivers are FDI, interest rate convergence, and geographic proximity. We find that during the GFC, only bank asset-side exposure and FDI linkages contribute to a significant increase in the co-movement of the returns. Our findings could have implications for portfolio decisions and may trigger new international diversification strategies not purely based on geographic factors. The fact that financial linkages enhance the co-movements in real estate returns in distressed periods calls for the reconsideration of real estate assets in a mixed-asset context. 


\section{Measures of financial, economic, and geographic integration}

\subsection{Asset-side and liability-side bank exposure}

It is important to account for this measure of financial integration since the international banking system is becoming a more important conduit for the transfer of capital across countries, as has been shown by the dramatic increase in international bank foreign claims in the last 20 years prior to the crisis (McGuire and Tarashev, 2007). The increase in cross-border bank flows can be explained by the global banking channel recently modelled by Bruno and Shin (2014). The main idea is that banks in advanced economies rely heavily on wholesale funding - much of which may have come from abroad, thus making them more exposed to changes in the balance sheets of global banks. We argue that the co-movement between property returns of two countries can increase if either the assets or the liabilities of banks' balance sheets are more heavily exposed to foreign banks' lending and borrowing. The balance-sheet exposure can be reflected by an increase in a bank's assets or liabilities against the counterparty foreign country.

International banks may grow their foreign claims portfolio through two channels. They can establish affiliates in different countries and extend claims locally through their branches and subsidiaries in these countries. Alternatively, they can extend cross-border flows by booking the claims and liabilities from outside the recipient or host countries. An increase in foreign bank assets exposure is associated with higher credit risk, also reflecting an increase in leverage. For example, a liquidity problem of the borrowers (e.g. foreclosure and bankruptcy) increases the credit risk of the lender. The latter can respond to that by decreasing its balance sheet and reducing both foreign and domestic credit supply. Moreover, since large banks borrow from the wholesale market, most liabilities are short-term positions in foreign currency while most assets are long-term positions in local currency, increasing the maturity mismatch and the currency risk. On the liability side, in turn, there is a funding risk since banks not only lend to foreign borrowers but also rely heavily on funding from abroad, especially from other banks. The growth of foreign bank inflows can lead to an increase in asset prices either directly, by pushing up demand for domestic assets, or by facilitating more rapid credit growth in addition to domestic deposits and other domestic sources. The strong credit growth in many developed countries prior to the GFC could have been driven by the increasing dominance of capital flows from foreign banks, meaning that these countries were more prone to international developments in credit markets (Allen et al., 2011). 


\subsection{Bilateral trade and FDI}

International trade and foreign direct investment can foster business cycle synchronization across countries through demand and supply side channels, so that countries with stronger trade or FDI linkages can be more heavily exposed to co-movements in asset values than countries with little trade or investment exposure. Beine, Cosma, and Vermeulen (2010) and Wälti (2010) show, for example, that an increase in trade can lead to stronger stock market dependence across countries. More recently, Asgharian, Hess, and Liu (2013) finds that trade linkages are the best measure to capture co-movements in equity returns.

\subsection{Geographic proximity}

Another measure to capture the business cycle synchronization across countries widely used in spatial econometrics is geographic proximity. The reason is that neighboring countries often keep close economic relationships and therefore, listed real estate, similar to the general stock market, can be more strongly affected by the economic cycle of the counterparty countries. Therefore, as Fazio (2007) and Orlov (2009) argue, geographically close countries would have stronger trade and financial linkages as a result. Miao, Ramchander, and Simpson (2011) explore correlations among real estate returns in 16 US metropolitan areas and find that the strongest correlation appears to be in geographically adjacent regions. A similar result has been found for stock returns by Flavin, Hurley, and Rousseau (2002). Portes and Rey (2005) find that geographical distance presents a barrier to international equity flows. Zhu et al. (2013) argue that geographic closeness is important for explaining housing return and volatility co-movements, however, economic proximity is an additional source of co-variations.

\subsection{Exchange rate convergence}

The co-movement channel through exchange rate convergence is straightforward through a decrease in currency risk premiums, thereby decreasing the cost of hedging currency risk. This should increase the attractiveness of the foreign markets and lead to a more harmonized interdependence between listed property returns in different countries. The majority of the studies that have studied the role of exchange rate similarity in the context of international market dependence find that exchange rate volatility significantly negatively impacts on financial market co-movements (see Bodart and Reding, 1999; Beine et al., 2010; Asgharian et al., 2013). 


\subsection{Interest rate convergence}

Previous research uses the degree of interest rate convergence across countries as a measure of financial integration (see Marston, 1997; Asgharian et al., 2013) because it can capture the degree of financial liberalization. The co-movement across returns in countries with high interest rate convergence can be explained by arbitrage-free conditions leading to more efficient capital relocation.

\subsection{Inflation convergence}

It is also important to account for inflation convergence across countries as a measure of proximity since real estate provides a good hedge against inflation (e.g. Ely and Robinson, 1997; Hoesli, Lizieri, and MacGregor, 2008). Transmission occurs when the existence of purchasing power parity (PPP) induces investors to try to hedge domestic assets with foreign real estate, since inflation differences among those countries do not exist (see Cooper and Kaplanis, 1994). Previous research shows that inflation convergence has a positive impact on stock market co-movement. Hardouvelis, Malliaropulos, and Priestley (2006) find a positive relationship between inflation proximity and stock market integration among euro area countries, while Johnson and Soenen (2002) reach a similar conclusion for Asian economies. More recently, Asgharian et al. (2013) find, using a spatial panel model for a sample of 41 countries, that inflation convergence increases the co-movement across equity market returns.

\section{Methodology and data}

\subsection{The dynamic spatial panel model}

We employ a dynamic spatial panel model to estimate the spatial dependence in the international listed real estate market. The dependence is captured by a weight, based on the closeness between each of two countries. To account for different sources of spatial correlation, previous literature proposes a variety of ways to model the spatial autoregressive process (e.g. Anselin, 2006; LeSage and Pace, 2009). As Asgharian et al. (2013) argue, compared with the spatial error model and the spatial lag model, the dynamic spatial panel model can nest both models and can produce unbiased coefficient estimates under the data generating process. The model is given as: 
$Y_{t}=\rho W_{t} Y_{t}+\varphi Y_{t-1}+\delta W_{t-1} Y_{t-1}+X_{t} \beta+W_{t} X_{t} \lambda+Z_{t} \gamma+D_{N} \alpha+e_{t}$

with $t=1, \ldots, T$.

Here $Y_{t}$ denotes an $N \times 1$ vector of dependent variables, with $Y_{t}=\left(y_{1, t}, y_{2, t}, \ldots, y_{N, t}\right)^{\prime}$, while $y_{i, t}$ stands for the return of the EPRA/NAREIT index of listed property companies in country $i$ in period $t$, with $i=1, \ldots, N$ and $t=1, \ldots, T . Y_{t-1}$ is the vector of lagged returns. $\varphi$ is the autoregressive coefficient. $W_{t}$ is the standardized non-stochastic spatial dependence weight matrix that generates the cross-country correlation. When constructing the weight matrix, we use time varying weights, since shifts in weights can have implications on the estimated coefficients. $W_{t} Y_{t}$ captures the contemporaneous return co-movements, and $\rho$ is the spatial autoregressive parameter. $W_{t-1} Y_{t-1}$ accounts for the lagged interdependence in the returns, with $\delta$ the spillover parameter.

$X_{t}$ is a $N \times K$ matrix that controls for country-specific factors in period $t$, including the credit-toGDP ratio, inflation, country openness, real estate equity market capitalization, house prices, exchange rate, and interest rate. Market capitalization, house prices, and inflation are first-log transformed and then first-order differenced. The credit-to-GDP ratio, exchange rate, and interest rate are calculated as a growth rate by using the first difference. $\beta$ is the $K \times 1$ coefficient vector which measures the average effect of changes in the country-specific variables on property returns in the respective country.

$W_{t} X_{t}$ captures the impact of the foreign explanatory variables averaged across countries using the same weight matrix. $\lambda$ is a $K \times 1$ coefficient vector, which captures the contemporary average effect of changes in a foreign country-specific variable on the return in the domestic country.

$\mathrm{Z}_{t}$ is an $N \times 2$ matrix accounting for global factors, including global leverage and the growth rate of the oil price. We include global factors to control for return co-movements that are not explained by country-specific variations but that are due to changes on the global markets. 
$D_{N}$ includes $N-1$ country dummy variables and 3 seasonal dummy variables. Since we use timevarying weights, we use country dummy variables instead of country-specific fixed effects. The dummy variables represent time-invariant individual market characteristics, such as investors' risk preference. $e_{N, t}$ is an $N \times 1$ vector of disturbances at period $t$.

The model in (1) is solved by a maximum likelihood estimation. The log-likelihood function that is to be maximized is given by:

$$
L L=\sum_{t=1}^{T} \ln \left|I_{N}-\rho W_{t}\right|-\frac{N T}{2} \ln \left(2 \pi \hat{\sigma}^{2}\right)-\frac{\sum_{t=1}^{T} \hat{e}_{t}^{\prime} \hat{e}_{t}}{2 \hat{\sigma}^{2}},
$$

with $\hat{e}_{t}=Y_{t}-\hat{\rho} W_{t} Y_{t}-\hat{\varphi} Y_{t-1}-\hat{\delta} W_{t-1} Y_{t-1}-X_{t} \hat{\beta}-W_{t} X_{t} \hat{\lambda}-Z_{t} \hat{\gamma}+D_{N} \hat{\alpha}$. Equation (1) can be written in reduced form as:

$$
Y_{N, t}=\left(I_{N}-\rho W_{N, t}\right)^{-1}\left(\varphi Y_{N, t-1}+\delta W_{N, t-1} Y_{N, t-1}+X_{N, t} \beta+W_{N, t} X_{N, t} \lambda+Z_{t} \gamma+D_{N} \alpha+e_{N, t}\right)
$$

We define $V_{t}=\left(I_{N}-\rho W_{N, t}\right)^{-1}$ and $A_{t}=V_{t}\left(I_{N} \varphi+\delta W_{N, t-1}\right)$ so that:

$$
Y_{t}=\sum_{p=0}^{\infty} A_{t-p}^{p} V_{t-p}\left(X_{t-p} \beta+W_{t-p} X_{t-p} \lambda+Z_{t-p} \gamma+D \alpha+e_{t-p}\right)
$$

Since $\left(I_{N}-\rho W_{N, t}\right)^{-1}=I_{N}+\rho W_{N, t}+\rho^{2} W_{N, t}^{2}+\rho^{3} W_{N, t}^{3}+\cdots$, Equation (2) implies a spatial multiplier effect (Anselin, 2006; LeSage and Pace, 2009). Any change in economic variables or unexpected shocks in one country will also affect the remaining countries through the spatial weight matrix. It is not only the first order 'neighbors', $\rho W_{N, t}$, that are affected: the neighbor's neighbors are also impacted through the spatial multiplier effect, $\rho^{2} W_{N, t}^{2}, \rho^{3} W_{N, t}^{3}$, etc. In the end, the shock can have a feed-back effect on the country of origin of the shock.

Following a unit return shock in country 1, the average unscaled response of the returns in all countries in the subsequent period $P$ can be calculated as (Pesaran and Shin, 1998): 
$\left[\begin{array}{c}\psi_{1,1, P} \\ \psi_{1,2, P} \\ \vdots \\ \psi_{1, N, P}\end{array}\right]=\frac{1}{T} \sum_{1}^{T} \sum_{p=0}^{P} A_{t+p}^{P} V_{t+p} \frac{\Omega_{e}}{\sigma_{1}^{2}}\left[\begin{array}{c}1 \\ 0 \\ \vdots \\ 0\end{array}\right]$,

where $\sigma_{1}^{2}$ is the variance of country $1, \psi_{1, j, P}$ is the response of the real estate equity market in the $j$ th country to the shock in country 1 . Since $\Omega_{e}$ is assumed to be a diagonal matrix (i.e., the error terms are independent from each other), the cross-border transmission of a country-specific shock entirely occurs through the spatial structure of $V$. This differs from time series models like vector autoregressive (VAR) models where the cross-sectional transmission of shocks largely depends on the covariance matrix of the error terms. Based on Equation (5), the average spillover effect of a one unit return shock in the $i$ th country in period $P$ is:

$\psi_{i, P}^{i m p}=\frac{1}{N-1} \sum_{j=1, j \neq i}^{N} \psi_{i, j, P}$

When $P=0$, the average immediate effect of a shock in country $i$ to returns in one country on returns in all other countries is:

$\psi_{i, 0}^{i m p}=\frac{1}{N-1} \sum_{j=1, j \neq i}^{N} \psi_{i, j, 0}=\frac{1}{T} \sum_{i=1}^{T} \frac{\sum_{i \neq j}^{N} V_{i j, t}}{N-1}$.

\subsection{Spatial weight matrices}

The spatial weight matrix plays a crucial role in spatial econometric models because the estimated spatial correlation depends on the specification of weight matrix. This paper assesses the impact of a variety of financial and economic channels, including bank balance-sheet exposure, FDI and trade, geographic distance as well as interest rate, inflation, and exchange rate convergence. In general, the weight matrix is constructed in two steps. First, we calculate the distance or proximity between each of two markets. Then we transform the measure of proximity to a weight that is standardized. 


\subsubsection{Distance measurements}

\section{Asset-side bank linkages}

The increase in spatial correlations can be caused by the increased financial integration, which may be associated with either asset-side or liability-side risks. On the asset side, we use bilateral bank claims data for constructing the asset weights. The asset-side exposure matrix is calculated from the share of claims of reporting country $i$ to country $j$ divided by total bank claims of the reporting country $i$ to all countries in the sample:

$$
F_{i, j, t}^{a s s e t}=\frac{\text { Claim }_{i, j, t}}{\sum_{k} \text { Claim }_{i, k, t}} .
$$

\section{Liability-side bank linkages}

For the liability weights, we reverse the direction of assignment by country. The liability-side exposure matrix is calculated from the share of liabilities of country $i$ to country $j$, divided by total liabilities of country $i$ or in terms of counterparty claims - claims of country $j$ to country $i$ divided by total bank claims of country $j$ to all countries in the sample:

$$
F_{i, j, t}^{\text {liability }}=\frac{\text { Claim }_{j, i, t}}{\sum_{k} \text { Claim }_{j, k, t}} .
$$

\section{FDI linkages}

Another linkage that may capture the equity market dependence is bilateral FDI. We calculate the importance of country $j$ for country $i$ by taking the FDI between the two countries as a proportion of the total FDI of country $i$ with all other countries:

$F_{i, j, t}^{F D I}=\frac{\text { Outward }_{i, j, t}+\text { Outward }_{i, j, t}}{\sum_{k} \text { Outward }_{i, k, t}+\sum_{k} \text { Outward }_{k, i, t}}$. 
The FDI linkage can also be defined based on the outward and inward FDI separately (e.g. $F_{i, j, t}^{\text {Out }}=\frac{\text { Outward }_{i, j, t}}{\sum_{k} \text { Outward }_{i, j, t}}$, and $F_{i, j, t}^{\text {In }}=\frac{\text { Inward }_{i, j, t}}{\sum_{k} \text { Inward }_{i, j, t}}$ ) but both weights generate very similar results, and also similar results with the weight based on total inward and outward FDI. The reason may be in the small difference between the outward FDI flow and the inward FDI flow, while bank liability and asset flows show substantial differences across countries (see Exhibit 4). Exhibit 4 shows that the US banks are the largest borrowers while German banks are the largest lenders. Therefore, we only report the results based on total FDI. ${ }^{1}$

\section{Trade linkages}

We calculate the importance of country $j$ for country $i$ by taking the trade between the two countries as a proportion of the total trade of country $i$ with all other countries:

$$
F_{i, j, t}^{\text {Trade }}=\frac{\text { Export }_{i, j, t}+\text { Export }_{i, j, t}}{\sum_{k} \operatorname{Export}_{i, k, t}+\sum_{k} \text { Export }_{k, i, t}}
$$

As with the FDI linkage, we also try the trade weight based only on exports or imports separately. The two matrices generate very similar results with the weight based on total trade. Detailed results are available on request.

\section{Exchange rate volatility}

In the market with less volatile exchange rates, higher correlation may appear between the two markets. The exchange volatility between the two countries is estimated as the standard deviation of the daily bilateral exchange rate during each year.

\section{Interest rate differential and Inflation differential}

We use the difference in the 3-month money market rate (IR) between country $i$ and country $j$ and also account for fluctuations in exchange rates by subtracting the purchasing power parity (PPP) between the two countries:

\footnotetext{
${ }^{1}$ Detailed results remain available on request.
} 
$F_{i, j, t}^{I R}=\left|I R_{i, t}-I R_{j, t}-E_{t-1}\left(\frac{F X_{i j, t}}{F X_{i j, t-1}}-1\right)\right|$,

where $F X_{i, j}$ is the expected growth of the price of one unit of currency in country $j$ in terms of the currency in country $i$, and $I R$ is the interest rate.

Similarly, the weight of inflation differential is constructed as:

$F_{i, j, t}^{c p i}=\left|I N F L_{i, t}-I N F L_{j, t}-E_{t-1}\left(\frac{F X_{i j, t}}{F X_{i j, t-1}}-1\right)\right|$,

where $F X_{i, j}$ is the expected growth of the price of one unit of currency in country $j$ in terms of the currency in country $i$, and INFL is the inflation rate.

\section{Geographic proximity}

Finally, as is the case for real estate, geographic proximity can be an important driver for real estate price spillovers. We measure geographic proximity based on the distance between the capital cities of each pair of countries:

$F_{i, j}^{D}=D_{i, j}$.

\subsubsection{Contiguity weight matrix}

In the second step, we convert these $F$ matrices into the corresponding continuity matrix $c$, which is defined as:

$$
c_{i, j, t}=1-\frac{\max _{j, t} F_{i, j, t}-F_{i, j, t}}{\max _{j, t} F_{i, j, t}-\min _{j, t} F_{i, j, t}}
$$

when $F$ is a measure of closeness (e.g., trade, FDI), or 
$c_{i, j, t}=1-\frac{F_{i, j, t}-\min _{j, t} F_{i, j, t}}{\max _{j, t} F_{i, j, t}-\min _{j, t} F_{i, j, t}}$,

when $F$ is a measure of distance (e.g. geographic distance, openness similarity). Matrix $c$ is then row standardized to become the weight matrix $W$.

If the weight matrix is constructed skipping the second step, the matrix will remain symmetric. The second step assures that the matrix is not necessarily symmetric, so that even if country $i$ is an important neighbor for country $j$ (i.e. $c_{j i}$ is close to one), country $j$ may be not important for country $j$ (i.e. $c_{i j}$ is close to zero). The weight matrix is then obtained from $\mathrm{c}$ through row standardization, such that for each $i, \sum_{j, t} w_{i, j, t}=1$.

\subsection{Phase dependent linkages}

In this paper, we also investigate whether the spatial dependence changes during times of market distress. During the GFC, the international dependence may increase due to contagion effects or the loss of investors' confidence. Because of the relatively short crisis period, we decided not to split the data and not to run the model separately in each phase. Instead, we allow for time-varying spatial linkages. For this reason, we have allowed the spatial weights to change over time; therefore the increase in the coefficient is purely due to the increase in the intensity, rather than to change in the weight itself. Specifically, we use a logit non-linear smooth transition process (van Dijk, Terasvirta, and Franses, 2002) to analyse whether the spatial coefficients change significantly during the 2007-2009 financial crisis. Compared with the simple dummy variable approach, the smooth transition process allows for more efficient regime switches from one phase to another. Incorporating these modifications, Equation (1) becomes:

$$
\begin{aligned}
& Y_{N, t}=\rho_{t} W_{N, t} Y_{N, t}+\varphi Y_{N, t-1}+\delta_{t} W_{N, t-1} Y_{N, t-1}+X_{N, t} \beta+W_{N, t} X_{N, t} \lambda+Z_{t} \gamma+D_{N}+e_{N, t}, \\
& \rho_{t}=\rho+\rho_{p 1} \frac{\exp (t-s 1)}{1+\exp (t-s 1)}, \\
& \delta_{t}=\delta+\delta_{p 1} \frac{\exp (t-s 1)}{1+\exp (t-s 1)}
\end{aligned}
$$


where $\rho$ is the coefficient of spatial dependence in the normal period and $\rho_{p 1}$ captures the change of the coefficient in the crisis period starting in 2007Q4.

\subsection{Data}

Our estimation sample includes the following 14 countries: Australia, Belgium, Canada, Finland, France, Germany, Italy, Japan, the Netherlands, Spain, Sweden, Switzerland, the UK, and the US, since long time series for listed property returns are only available for these countries. The estimation period ranges from 1990Q1 to 2012Q4. The dependent variable is the quarterly log difference of the FTSE EPRA/NAREIT listed property index for each country. The national indices are taken from the European Public Real Estate Association (EPRA), an organization that represents Europe's publicly listed property companies and tracks the performance of companies engaged in the ownership, trading, and development of income-producing real estate. The fundamental business of those listed real estate companies is investing in and operating real estate assets, with income being generated from renting these assets to other organizations. Exhibit 3 shows the indices of the quarterly listed property prices. We can see that the indices in the majority of the countries soared up until 2007 and then dropped dramatically during the GFC.

$<$ Exhibit 3 about here $>>$

While the main focus of the paper is to look at the spatial linkages across listed property returns, we control for country-specific factors that are associated with demand and supply drivers of real estate markets. These variables include the change in the share of credit from domestic banks to the private non-financial sector relative to GDP, equity returns, house price growth, exchange rate growth vis-à-vis the US dollar, short-term interest rate change, and CPI inflation rate. We also include a measure of market capitalization of each country's listed property market taken from EPRA in order to account for size differences across the listed property markets in different countries. The macroeconomic variables are taken from the International Financial Statistics of the IMF, and complemented by data from OECD where IMF data is not available. House prices come from the BIS database and from Oxford Economics.

Moreover, to control for any return drivers associated with foreign trade and foreign investment 
activity of the country, we include a measure of openness taken from the World Heritage Foundation. We calculate openness by taking the average of the trade and the investment openness indices, which are part of the Index of Economic Freedom. In particular, trade freedom is defined as "the absence of tariff and non-tariff barriers that affect imports and exports of goods and services" (Heritage, 2016). Investment freedom is determined by a number of restrictions on foreign investment, such as restrictions on real estate purchases, national treatment of foreign investment, bureaucracy, expropriation of investment, foreign exchange, and capital controls, etc.

Since property return co-movements can be caused not only by bilateral linkages but also by global factors, we include oil prices and a measure of global financial leverage. The oil price is taken from Datastream. It is a good indicator of global economic cycles and inflation expectations. Global financial leverage, meanwhile, measures financial risk appetite. We follow Bruno and Shin (2014) who use global leverage measured by the US broker-dealer leverage to explain the global banking channel. US broker-dealer leverage is calculated as the sum of equity and total liabilities divided by equity, for which data comes from the US flow of funds. Bruno and Shin (2014) find that higher leverage significantly increases cross-border bank flows. Financial leverage of broker-dealers is closely negatively associated with the VIX index of implied S\&P stock market volatility and can therefore also be associated with international investors risk appetite.

Data for the trade matrix comes from the trade statistics of the OECD. Bilateral FDI flows are taken from the foreign direct investment statistics of the OECD. For bank balance-sheet exposure we use bilateral bank claims based on the consolidated bank statistics of the BIS using Table 9B. The consolidated statistics are based on the country of origin of the reporting bank and not on its location. It means that the claims from a bank's subsidiary are counted as claims by the country in which the bank is from. Exhibit 4 illustrates the bank asset and liability flows as well as the outward and inward FDI flows of Germany, Japan, UK, and US. Unlike outward and inward FDI, which is similar for each country, bank asset and liability flows are quite different across the four countries. Germany is the biggest net lender while the US is the biggest net borrower on average, over 19902012.

$<$ Exhibit 4 about here $>>$ 


\section{Results}

\subsection{Spatial linkages across international listed property returns}

Exhibit 1 shows the results for nine different model specifications. In each of the first eight models, a different spatial matrix is used. The ninth model is the restricted model which does not account for spatial correlations across the property returns. The likelihood ratio (LR) test suggests that incorporating the weight matrix can substantially improve the model fit compared to the restricted model.

Based on the spatial weights, we observe significant linkages within the same period across returns in different countries. The findings are robust to the spatial matrix that we use. Taken individually, each matrix can significantly explain the spatial co-movements. The contemporaneous coefficient of spatial dependence across the different models lies between 0.40 (bilateral trade) and 0.44 (interest rate convergence), so that all models deliver very similar results. Not only can geographic linkages among the countries contribute to spatial correlation across returns, but so can measures such as trade and investment proximity, as well as financial measures such as bank asset and liability exposure. This funding suggests that both credit risks on the asset side and funding risks on the liability side can be passed through to other countries through bank balance sheets, and can lead to co-movements in listed property returns. Furthermore, interest rate, inflation, and exchange rate similarity across countries also trigger stronger return dependencies.

We observe that global leverage which is significant in the restricted model turns insignificant once we account for spatial linkages. It may imply that global leverage in the restricted model could capture systemic risk in the globalized financial markets. The oil price also turns insignificant in most of the models except in the asset, liability, and FDI models. The significant oil price in the restricted model may thus capture cross-country synchronization of economic cycles.

$<$ Exhibit 1 about here $>>$

Regarding the country-specific variables, significant positive impact on returns is observed by the 
credit-to-GDP ratio, equity returns, market capitalization, openness, and the interest rate. The signs are in line with the economic theory. We find that while equity returns significantly explain property company returns, the impact of housing returns is insignificant. This might be because most of the listed real estate companies invest in commercial real estate rather than residential properties. Besides, although the major income flows of listed property companies come from the underlying real estate performance, in the short term the returns may be affected by trade noise (Glascock, Lu, and So, 2000), investors' sentiment spillover (Ambrose, Lee, and Peek, 2007), and extreme events (Simon and Ng, 2009) in the equity market. We show that real estate equity markets with larger capitalization have better performance, which is in line with previous research in this area. The availability of credit relative to the GDP ratio of a country is another driver of the overall return as more credit can increase the supply of real estate by developers and can foster the demand by investors. Short-term interest rates have a significantly negative impact on the performance of listed property companies because they are associated with higher funding costs and substitution effects to other asset classes which offer competitive returns.

Moreover, we observe that the average foreign house price has a significantly positive impact on domestic property company returns. The significant cross-country co-movements between listed and direct property may capture the internalization of the listed property companies invested in different real estate markets across the world. In turn, high average openness of the foreign countries and low domestic openness decrease domestic returns; this can be associated with the idea that if a country is more open to foreign investment, investors would more easily be able to distribute funds from less open to more open economies and decrease demand in the more open economy, hence lowering the returns.

\subsection{Economic significance versus statistical significance}

As shown in Exhibit 1, we can see that our results are robust against changes in the model specification and measures of spatial proximity. This might be due to the fact that the crosssectional dependence across the returns is predominantly caused by other global factors not captured by oil prices or financial leverage. In this case, we would always find a significant comovement coefficient $(\rho)$ irrespective of the weight matrix we used. To control for such unobserved 
global variations in returns, we account for the economic significance by running a simulation. We simulate 200 randomly generated weight matrices, and then run the estimation using these neighborhood matrices instead.

The results are presented in Exhibit 5. We plot out the upper and lower 95\% quantile of the loglikelihood of the simulated matrices together with the log-likelihoods of the models from Exhibit 1. Models above the upper dotted or solid line show a better performance than a randomly generated weight matrix. We can see that only asset-side exposure, FDI, interest rate convergence, and geographic distance outperform the random scenario. All other models fall within the confidence bands of the log-likelihood of the randomly generated weight matrix, suggesting that any other linkage matrix would yield similar results and hence, may not capture country-specific variations well but rather, global factors.

$<<$ Exhibit 5 about here $>>$

The model that best captures the co-movements across the listed property returns is bilateral bank asset exposure. ${ }^{2}$ Since we account for global leverage, we can rule out the possibility that the correlations are driven by systematic risk that is stemming from the increased bank balance-sheet cross-country dependence. Asset-side exposure could well capture the credit risk that can trigger a co-movement in real estate returns through a global banking channel. If the asset exposure of one country towards another country increases, liquidity shocks in the borrowing country may affect balance sheets of the lender and hence, banks in both regions may respond with changes in credit supply. For example, if the borrower faces a liquidity shortage and is not able to repay the loan, the lender may respond with a decrease in credit provision not only in the borrowing country but also in the domestic country and all other countries as well. A change in the credit provision would have implications on asset prices and thus cause stronger co-movements in their returns. The stronger the asset exposure towards a country, the larger the co-movement in returns would then be.

While the model with the asset exposure performs best, the model using liability exposure performs worst. In fact, it is the only model whose likelihood ratio lies below the confidence bands of the

${ }^{2}$ The better performance of the asset model can be due to the fact that the US is the largest borrower in our dataset, towards which most countries have an asset-side exposure. 
simulated matrix's log-likelihood. This can be explained by looking at the raw data from the BIS at Exhibit 4 . We can see that bank assets for each country differ strongly from bank liabilities. It means that some countries, like the US, are dominant net borrowers, whereas others, like Germany, are dominant net lenders. Hence, a difference in the performance of the liability model as compared to the asset model is to be expected. The poor performance of the liability model suggests that there are other drivers different from an increased liability-side exposure, which better capture the comovement in returns.

\subsection{The impact of the crisis on spatial linkages}

In order to assess whether the spatial linkages have changed with the onset of the GFC, we estimate a spatial model based on Equation (17). Exhibit 2 exhibits the results based on the models with asset exposure, FDI, interest rate, and geographic distance, as they are the ones that generate substantially higher log-likelihood value compared to the randomly generated weight matrix. $\rho_{p 1}$ is the phase dependent spatial coefficient and captures the change of the spatial coefficient $\rho$ during the crisis period. ${ }^{3}$ We can see that $\rho_{p 1}$ is significant in the model with the asset-side exposure and the model with FDI. The likelihood ratio test also confirms that adding the phase dependent spatial coefficient in those two models can substantially improve the model fit compared to the baseline case. The finding that the phase dependent coefficient is positive suggests that the comovement across listed property returns increases significantly during the crisis period in countries that have strong asset-side exposure or high FDI. This result is indicative of the strong spillover effects among the financial markets, especially due to the high foreign capital flow exposure. Investors should therefore account for such linkages across countries since even when geographically well diversified, financial integration can still drive return co-movements, as happened during the GFC. Geographic distance or interest rate convergence seems not to increase their impact on the spatial correlations during the crisis.

$<$ Exhibit 2 about here $>>$

\footnotetext{
${ }^{3}$ As a beginning of the crisis period we set the fourth quarter of 2007 . If we change the starting point of the GFC by one or two quarters, the results remain robust. This is because our smooth transition process allows a smooth switching to the other phase.
} 
Exhibit 6 and 7 show the average impact of a country-specific return shock on the returns in the remaining countries. We show results for Germany, Japan, UK, and US as these countries have the largest bank balance-sheet exposure. In general, we can see a much stronger impact stemming from the US than from the other three countries. Prior to the GFC, the US return shock is channelled through to the returns of the remaining countries via bilateral FDI and bank asset-side exposure. The impact of the US is even more pronounced during the GFC, particularly through the credit risk channel. During the pre-crisis period, on average, a one percent positive shock in one of the 14 countries will generate a contemporaneous impact of $0.044 \%$ increase in the rest of the countries. During the crisis, the average impact goes up to $0.074 \%$, more than $60 \%$ of the impact in the normal period. In the period before the GFC, a one percent positive shock in the US market will lead to a contemporaneous impact of $0.17 \%$ via the credit risk channel and during the crisis, the influence rises to $0.28 \%$, around four times higher than the average impact.

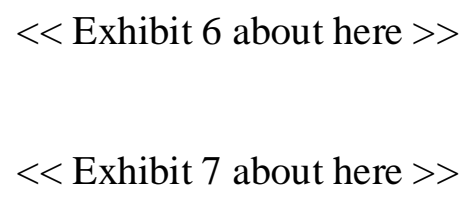

Similarly, a shock to UK-listed real estate stock returns would have a stronger effect on the comovement of returns during the crisis via the banking channel. The change in the shock impact for Germany and Japan is smaller, but generally the same pattern is observed. 


\section{Conclusion}

This paper investigates the spatial linkages between listed property company returns in 14 countries using different measures of spatial proximity and distinguishing between normal periods and distressed periods. The purpose is to identify which are the most important linkages that capture the return co-movements across the countries. Risk-hedging through global diversification can be affected if country-specific shocks are passed through to other countries through their financial or economic integration or geographic proximity, thereby increasing the co-movement of real estate returns.

There are different channels of transmitting variations in listed property returns in one country to returns in other countries. The most common spatial dependence widely studied in the literature is through geographic proximity. Our study extends existing spatial research by looking at a wider range of linkages across property returns accounting for a number of closeness indicators, such as bank asset exposure, bank liability exposure, bilateral FDI, bilateral trade, interest rate convergence, exchange rate convergence, inflation convergence, and geographic distance. It is important to account for measures of financial integration in particular since the international banking system is becoming a more important conduit for the transfer of capital across countries, with cross-border bank flows strongly increasing in the last 20 years. We can show that bank asset exposure best captures the co-movements in returns providing evidence for a credit risk channel. Other important drivers are bilateral FDI, interest rate convergence, and geographic proximity. We find that during the GFC, only bank asset-side exposure and bilateral FDI linkages contribute to a significant increase in the co-movement of returns. Our findings have implications for portfolio decisions and suggest that international diversification strategies should not be based purely on geographic factors. The finding that financial linkages enhance the co-movements in real estate returns during a financial crisis calls for the reconsideration of the role of real estate in a mixedasset context. 


\section{Exhibit 1: Models using different measures of spatial proximity to account for spatial correlation}

Note: Models estimated from 1990Q1 to 2012Q4. Dependent variable is the log difference of the listed property index from EPRA. The equation $Y_{N, t}=\rho W_{N, t} Y_{N, t}+\varphi Y_{N, t-1}+\delta W_{N, t-1} Y_{N, t-1}+X_{N, t} \beta+W_{N, t} X_{N, t} \lambda+Z_{t} \gamma+D_{N} \alpha+e_{N, t}$ is estimated using a Maximum Likelihood. $\rho$ is the coefficient for spatial correlation across property returns. Explicit description of the construction of the weight matrices is provided in Chapter 2.2. $\varphi$ is the autoregressive domestic return coefficient; $\delta$ stands for the lagged spillover effect of foreign returns. $\beta$ measures the effect of the domestic explanatory variables while $\lambda$ captures the average effect of the foreign country-specific variables. The country-specific variables are: creditto-GDP growth, equity return, house price growth, market capitalization growth, openness, exchange rate growth, long-term interest rate growth, and inflation growth lagged by one period. $\gamma$ is the coefficient vector of the global factors that include oil price growth and global leverage approximated by US broker-dealer leverage. Country-specific dummy variables and seasonal dummy variables are also included but not reported. Model 9 is estimated using the equation $Y_{N, t}=\varphi Y_{N, t-1}+X_{N, t} \beta+\lambda W_{N, t} X_{N, t}+Z_{t} \gamma+D_{N} \alpha+e_{N, t}$ not accounting for spatial return linkages. LR test compares the goodness of fit between the restricted model and the model with spatial weight matrix. It asymptotically follows a Chi-square distribution with 10 degrees of freedom. The null hypothesis is no significant difference in the goodness of fit between the restricted model and spatialmodel. Standard deviations are in parentheses. ** and *denote significance at the $1 \%$, and $5 \%$ levels, respectively.

\begin{tabular}{|c|c|c|c|c|c|c|c|c|c|}
\hline & $\begin{array}{c}\text { Model 1: } \\
\text { Bank asset } \\
\text { exposure }\end{array}$ & $\begin{array}{c}\text { Model 2: } \\
\text { Bank } \\
\text { liability } \\
\text { exposure }\end{array}$ & $\begin{array}{l}\text { Model 3: } \\
\text { Bilateral } \\
\text { FDI }\end{array}$ & $\begin{array}{l}\text { Model 4: } \\
\text { Bilateral } \\
\text { trade }\end{array}$ & $\begin{array}{l}\text { Model 5: } \\
\text { Exchange } \\
\text { rate } \\
\text { converg- } \\
\text { ence }\end{array}$ & $\begin{array}{c}\text { Model 6: } \\
\text { Interest } \\
\text { rate } \\
\text { converg- } \\
\text { ence }\end{array}$ & $\begin{array}{l}\text { Model 7: } \\
\text { Inflation } \\
\text { converg- } \\
\text { ence }\end{array}$ & $\begin{array}{c}\text { Model 8: } \\
\text { Geo- } \\
\text { graphic } \\
\text { proximity }\end{array}$ & Model 9: \\
\hline$\rho$ & $\begin{array}{l}0.4089^{* *} \\
(0.0391)\end{array}$ & $\begin{array}{l}0.4074^{\text {** }} \\
(0.0405)\end{array}$ & $\begin{array}{l}0.4090^{* *} \\
(0.0401)\end{array}$ & $\begin{array}{l}0.3971^{\text {** }} \\
(0.0373)\end{array}$ & $\begin{array}{l}0.4218^{* *} \\
(0.0438)\end{array}$ & $\begin{array}{l}0.4416^{* *} \\
(0.0402)\end{array}$ & $\begin{array}{l}0.4363^{\text {** }} \\
(0.0412)\end{array}$ & $\begin{array}{l}0.4374^{\text {** }} \\
(0.0381)\end{array}$ & \\
\hline$\phi$ & $\begin{array}{r}0.0428 \\
(0.0235)\end{array}$ & $\begin{array}{r}0.0556 \\
(0.0236)\end{array}$ & $\begin{array}{r}0.0454 \\
(0.0238)\end{array}$ & $\begin{array}{r}0.0524 \\
(0.0236)\end{array}$ & $\begin{array}{r}0.0595 \\
(0.0234)\end{array}$ & $\begin{array}{r}0.0507 \\
(0.0236)\end{array}$ & $\begin{array}{r}0.0478 \\
(0.0235)\end{array}$ & $\begin{array}{l}0.0559^{*} \\
(0.0235)\end{array}$ & $\begin{array}{l}0.0483^{*} \\
(0.0208)\end{array}$ \\
\hline$\delta$ & $\begin{array}{l}-0.0439 \\
(0.0324)\end{array}$ & $\begin{array}{l}-0.0616 \\
(0.0356)\end{array}$ & $\begin{array}{l}-0.0478 \\
(0.0345)\end{array}$ & $\begin{array}{l}-0.0538 \\
(0.0349)\end{array}$ & $\begin{array}{r}-0.0941^{* *} \\
(0.0358)\end{array}$ & $\begin{array}{l}-0.0559 \\
(0.0356)\end{array}$ & $\begin{array}{l}-0.0753^{*} \\
(0.0371)\end{array}$ & $\begin{array}{r}-0.0731^{*} \\
(0.0349)\end{array}$ & \\
\hline$\beta$ & & & & & & & & & \\
\hline $\begin{array}{l}\text { Credit-to- } \\
\text { GDP }\end{array}$ & $\begin{array}{l}0.4767^{* *} \\
(0.1647)\end{array}$ & $\begin{array}{l}0.5082^{* *} \\
(0.1687)\end{array}$ & $\begin{array}{l}0.4537^{* *} \\
(0.1641)\end{array}$ & $\begin{array}{l}0.4954^{\text {** }} \\
(0.1662)\end{array}$ & $\begin{array}{l}0.5075^{* *} \\
(0.1653)\end{array}$ & $\begin{array}{l}0.5082^{* *} \\
(0.1643)\end{array}$ & $\begin{array}{l}0.4901^{* *} \\
(0.1658)\end{array}$ & $\begin{array}{l}0.4705^{* *} \\
(0.1652)\end{array}$ & $\begin{array}{l}0.7533^{* *} \\
(0.1774)\end{array}$ \\
\hline Equity & $\begin{array}{l}0.1898^{* *} \\
(0.0382)\end{array}$ & $\begin{array}{l}0.1795^{* *} \\
(0.0392)\end{array}$ & $\begin{array}{l}0.1688^{* *} \\
(0.0383)\end{array}$ & $\begin{array}{l}0.1698^{\text {*** }} \\
(0.0383)\end{array}$ & $\begin{array}{l}0.2031^{* *} \\
(0.0361)\end{array}$ & $\begin{array}{l}0.1910^{* *} \\
(0.0369)\end{array}$ & $\begin{array}{l}0.1879^{* *} \\
(0.0367)\end{array}$ & $\begin{array}{l}0.1872^{* *} \\
(0.0368)\end{array}$ & $\begin{array}{l}0.3804^{* *} \\
(0.0328)\end{array}$ \\
\hline $\begin{array}{l}\text { House } \\
\text { price }\end{array}$ & $\begin{array}{l}-0.1010 \\
(0.1003)\end{array}$ & $\begin{array}{l}-0.0777 \\
(0.1025)\end{array}$ & $\begin{array}{l}-0.0793 \\
(0.1005)\end{array}$ & $\begin{array}{r}-0.0538 \\
(0.1011)\end{array}$ & $\begin{array}{l}-0.0668 \\
(0.1010)\end{array}$ & $\begin{array}{l}-0.0769 \\
(0.1003)\end{array}$ & $\begin{array}{l}-0.0629 \\
(0.1006)\end{array}$ & $\begin{array}{l}-0.0800 \\
(0.1005)\end{array}$ & $\begin{array}{l}0.1319 \\
(0.1084)\end{array}$ \\
\hline Market & $0.2608^{* *}$ & $0.2689^{* *}$ & $0.2595^{* *}$ & $0.2690^{* *}$ & $0.2686^{* *}$ & $0.2660^{* *}$ & $0.2652^{* *}$ & $0.2656^{* *}$ & $\begin{array}{r}0.3068^{* *} \\
22\end{array}$ \\
\hline
\end{tabular}




\begin{tabular}{|c|c|c|c|c|c|c|c|c|c|}
\hline cap. & $(0.0128)$ & $(0.0131)$ & $(0.0128)$ & $(0.0130)$ & $(0.0128)$ & $(0.0128)$ & $(0.0129)$ & $(0.0129)$ & $(0.0140)$ \\
\hline \multirow{2}{*}{ Openness } & $0.1288^{* *}$ & 0.0950 & $0.0931^{*}$ & $0.0885^{* *}$ & $0.0845^{* *}$ & $0.1051^{* *}$ & 0.1067 & $0.1076^{* *}$ & 0.0548 \\
\hline & $(0.0523)$ & $(0.0552)$ & $(0.0464)$ & $(0.0186)$ & $(0.0381)$ & $(0.0377)$ & $(0.0544)$ & $(0.0494)$ & $(0.0541)$ \\
\hline \multirow{2}{*}{$\begin{array}{l}\text { Exchange } \\
\text { rate }\end{array}$} & 0.0004 & 0.0003 & 0.0004 & 0.0005 & 0.0006 & 0.0006 & 0.0006 & 0.0005 & 0.0010 \\
\hline & $(0.0018)$ & $(0.0018)$ & $(0.0018)$ & $(0.0018)$ & $(0.0018)$ & $(0.0018)$ & $(0.0018)$ & $(0.0018)$ & $(0.0019)$ \\
\hline \multirow{2}{*}{$\begin{array}{l}\text { Interest } \\
\text { rate }\end{array}$} & $-0.0109^{* *}$ & $-0.0099^{* *}$ & $-0.0100^{* *}$ & $-0.0093^{* *}$ & $-0.0090^{* *}$ & $-0.0086^{* *}$ & $-0.0093^{* *}$ & $-0.0091^{* *}$ & $-0.0058^{*}$ \\
\hline & $(0.0024)$ & $(0.0025)$ & $(0.0024)$ & $(0.0025)$ & $(0.0024)$ & $(0.0025)$ & $(0.0025)$ & $(0.0024)$ & $(0.0026)$ \\
\hline \multirow{2}{*}{$\begin{array}{l}\text { Lagged } \\
\text { inflation }\end{array}$} & 0.2272 & 0.1958 & 0.1322 & 0.1136 & -0.1754 & -0.0776 & -0.0739 & -0.0977 & -0.2314 \\
\hline & $(0.5039)$ & $(0.5255)$ & $(0.5173)$ & $(0.5253)$ & $(0.5232)$ & $(0.5207)$ & $(0.5200)$ & $(0.5202)$ & $(0.4950)$ \\
\hline \multicolumn{10}{|l|}{$\lambda$} \\
\hline \multirow{2}{*}{$\begin{array}{l}\text { Credit-to- } \\
\text { GDP }\end{array}$} & 0.5090 & 0.1478 & 0.6879 & 0.3915 & $0.8143^{*}$ & 0.3607 & 0.4939 & 0.5920 & \\
\hline & $(0.3169)$ & $(0.3977)$ & $(0.3609)$ & $(0.3764)$ & $(0.4069)$ & $(0.4115)$ & $(0.4125)$ & $(0.4011)$ & \\
\hline \multirow{2}{*}{ Equity } & 0.0291 & 0.0767 & 0.0744 & 0.0986 & 0.0179 & 0.0432 & 0.0282 & 0.0382 & \\
\hline & $(0.0560)$ & $(0.0553)$ & $(0.0558)$ & $(0.0538)$ & $(0.0515)$ & $(0.0506)$ & $(0.0507)$ & $(0.0489)$ & \\
\hline \multirow{2}{*}{$\begin{array}{l}\text { House } \\
\text { price }\end{array}$} & $0.6822^{* *}$ & 0.2730 & $0.7089^{* *}$ & $0.5045^{* *}$ & $0.4610^{* *}$ & $0.6930^{* *}$ & $0.4686^{* *}$ & $0.6581^{* *}$ & \\
\hline & $(0.2374)$ & $(0.2374)$ & $(0.2460)$ & $(0.2231)$ & $(0.2486)$ & $(0.2818)$ & $(0.2582)$ & $(0.2949)$ & \\
\hline \multirow{2}{*}{$\begin{array}{l}\text { Market } \\
\text { cap. }\end{array}$} & -0.0047 & -0.0252 & 0.0056 & -0.0254 & -0.0037 & -0.0129 & 0.0056 & -0.0180 & \\
\hline & $(0.0355)$ & $(0.0335)$ & $(0.0402)$ & $(0.0314)$ & $(0.0307)$ & $(0.0317)$ & $(0.0340)$ & $(0.0306)$ & \\
\hline \multirow{2}{*}{ Openness } & $-0.1538^{* *}$ & $-0.1186^{* *}$ & -0.0689 & -0.0506 & -0.0655 & -0.0674 & $-0.1200^{* *}$ & -0.0864 & \\
\hline & $(0.0419)$ & $(0.0412)$ & $(0.0595)$ & $(0.0743)$ & $(0.0655)$ & $(0.0747)$ & $(0.0448)$ & $(0.0637)$ & \\
\hline \multirow{2}{*}{$\begin{array}{l}\text { Exchange } \\
\text { rate }\end{array}$} & -0.0004 & 0.0006 & -0.0099 & 0.0011 & 0.0040 & -0.0078 & -0.0077 & 0.0007 & \\
\hline & $(0.0078)$ & $(0.0049)$ & $(0.0075)$ & $(0.0042)$ & $(0.0062)$ & $(0.0096)$ & $(0.0059)$ & $(0.0253)$ & \\
\hline \multirow{2}{*}{$\begin{array}{l}\text { Interest } \\
\text { rate }\end{array}$} & $0.0151^{* *}$ & 0.0154 & 0.0105 & 0.0077 & 0.0077 & 0.0038 & 0.0090 & 0.0094 & \\
\hline & $(0.0058)$ & $(0.0072)$ & $(0.0068)$ & $(0.0073)$ & $(0.0061)$ & $(0.0065)$ & $(0.0062)$ & $(0.0059)$ & \\
\hline \multirow{2}{*}{$\begin{array}{l}\text { Lagged } \\
\text { inflation }\end{array}$} & -0.9232 & -0.8097 & -0.4653 & -0.4330 & 0.6983 & 0.6167 & 0.7455 & 0.5710 & \\
\hline & $(0.7496)$ & $(0.9081)$ & (0.9578) & $(0.8818)$ & $(0.8689)$ & $(0.9553)$ & $(0.9433)$ & $(0.8544)$ & \\
\hline \multicolumn{10}{|l|}{$\gamma$} \\
\hline \multirow{2}{*}{ Oil price } & $-0.0510^{* *}$ & $-0.0252^{* *}$ & $-0.0500^{* *}$ & -0.0311 & -0.0147 & -0.0201 & -0.0070 & -0.0153 & $-0.0373^{* *}$ \\
\hline & $(0.0182)$ & $(0.0191)$ & (0.0186) & (0.0186) & $(0.0186)$ & $(0.0186)$ & $(0.0207)$ & $(0.0187)$ & $(0.0186)$ \\
\hline Global & -0.0017 & -0.0002 & -0.0035 & -0.0017 & -0.0042 & -0.0039 & -0.0035 & -0.0045 & -0.0060 ** \\
\hline leverage & $(0.0027)$ & $(0.0026)$ & $(0.0027)$ & $(0.0026)$ & $(0.0027)$ & $(0.0027)$ & $(0.0026)$ & $(0.0027)$ & $(0.0028)$ \\
\hline LL & 1269.2 & 1244.9 & 1268.4 & 1252.6 & 1260.6 & 1266.5 & 1264.6 & 1269.5 & 1161.1 \\
\hline RMSE & 0.0080 & 0.0080 & 0.0078 & 0.0080 & 0.0079 & 0.0078 & 0.0079 & 0.0078 & 0.0094 \\
\hline $\operatorname{LR}(10)$ & $216^{* *}$ & $167^{* *}$ & $214^{* *}$ & $183^{* *}$ & $199^{* * *}$ & $210.8^{* *}$ & $207^{* *}$ & $216.8^{* *}$ & \\
\hline
\end{tabular}




\section{Exhibit 2: Model estimations with phase-dependent spatial coefficients}

Note: The alternative estimations for 1990Q1 to 2012Q4. Dependent variable is the log difference of listed property returns. The model is estimated as: $Y_{N, t}=\rho_{t} W_{N, t} Y_{N, t}+\varphi Y_{N, t-1}+\delta_{t} W_{N, t-1} Y_{N, t-1}+X_{N, t} \beta+W_{N, t} X_{N, t} \lambda+Z_{t} \gamma+D_{N}+e_{N, t}$ with $\rho_{t}=\rho+\rho_{p 1} \frac{\exp (t-s 1)}{1+\exp (t-s 1)}$ and $\delta_{t}=\delta+\delta_{p 1} \frac{\exp (t-s 1)}{1+\exp (t-s 1)}$ where $\rho$ is the coefficient of spatial dependence in the normal period and $\rho_{p 1}$ captures the change of the coefficient in the crisis period. $\delta$ captures the lagged spillover effect of foreign returns in the normal period and $\delta_{p 1}$ captures the change of the coefficient in the crisis period. The remaining coefficients are not reported for reasons of space. However, they remain robust comparable to the results in Exhibit 1 . LR test compares the goodness of fit between the model with phase-dependent spatial coefficients and the corresponding model with constant spatial coefficients (in Exhibit 1). It asymptotically follows a Chi-square distribution with 2 degrees of freedom. The null hypothesis is no significant difference in the goodness of fit between the two models. Standard deviations are in parentheses. **and* denote significance at the $1 \%$, and $5 \%$ levels, respectively.

\begin{tabular}{|c|c|c|c|c|}
\hline & $\begin{array}{c}\text { Model } \\
\text { 10: } \\
\text { Bank } \\
\text { asset } \\
\text { exposure }\end{array}$ & $\begin{array}{c}\text { Model } \\
\text { 11: } \\
\text { Bilateral } \\
\text { FDI }\end{array}$ & $\begin{array}{c}\text { Model } \\
\text { 12: } \\
\text { Interest } \\
\text { rate } \\
\text { converg- } \\
\text { ence }\end{array}$ & $\begin{array}{c}\text { Model 13: } \\
\text { Geo- } \\
\text { graphic } \\
\text { proximity }\end{array}$ \\
\hline$\rho$ & $\begin{array}{l}0.3696^{* *} \\
(0.0441)\end{array}$ & $\begin{array}{l}0.3730^{* *} \\
(0.0454)\end{array}$ & $\begin{array}{l}0.4078^{* *} \\
(0.0440)\end{array}$ & $\begin{array}{l}0.4072^{* *} \\
(0.0441)\end{array}$ \\
\hline$\rho_{p 1}$ & $\begin{array}{c}0.1293^{* *} \\
(00574)\end{array}$ & $\begin{array}{c}0.1287^{*} \\
(0.0601)\end{array}$ & $\begin{array}{r}0.1004 \\
(0.0616)\end{array}$ & $\begin{array}{r}0.0895 \\
(0.0621)\end{array}$ \\
\hline$\delta$ & $\begin{array}{l}-0.0544 \\
(0.0449)\end{array}$ & $\begin{array}{r}0.0493 \\
(0.0464)\end{array}$ & $\begin{array}{l}-0.0893 \\
(0.0469)\end{array}$ & $\begin{array}{c}-0.0945^{*} \\
(0.0454)\end{array}$ \\
\hline$\delta_{p 1}$ & $\begin{array}{r}0.0212 \\
(0.0603)\end{array}$ & $\begin{array}{r}0.0031 \\
(0.0640)\end{array}$ & $\begin{array}{r}0.0728 \\
(0.0657)\end{array}$ & $\begin{array}{r}0.0503 \\
(0.0654)\end{array}$ \\
\hline LL & 1273.0 & 1271.8 & 1270.5 & 1271.1 \\
\hline $\operatorname{LR}(2)$ & $9.4^{*}$ & $6.8^{*}$ & 4.4 & 3.2 \\
\hline
\end{tabular}


Exhibit 3: FTSE NAREIT/EPRA index of listed property companies in 14 countries

Australia

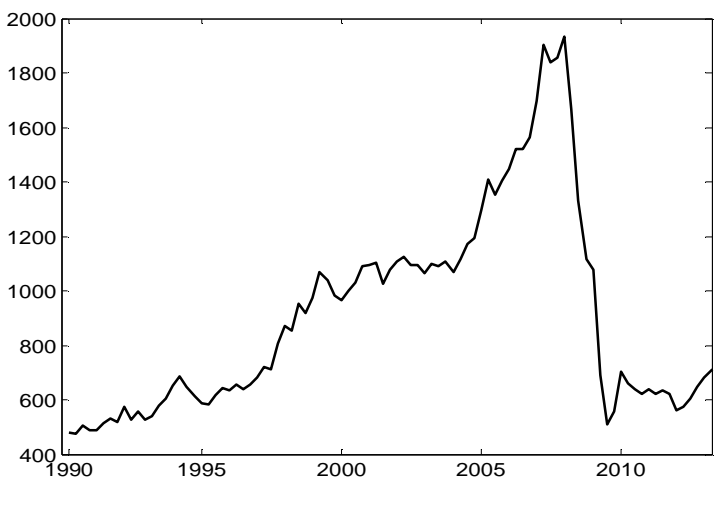

Canada

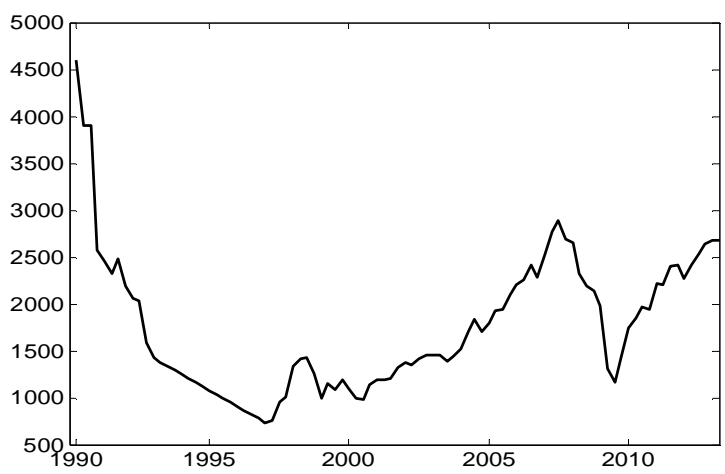

France

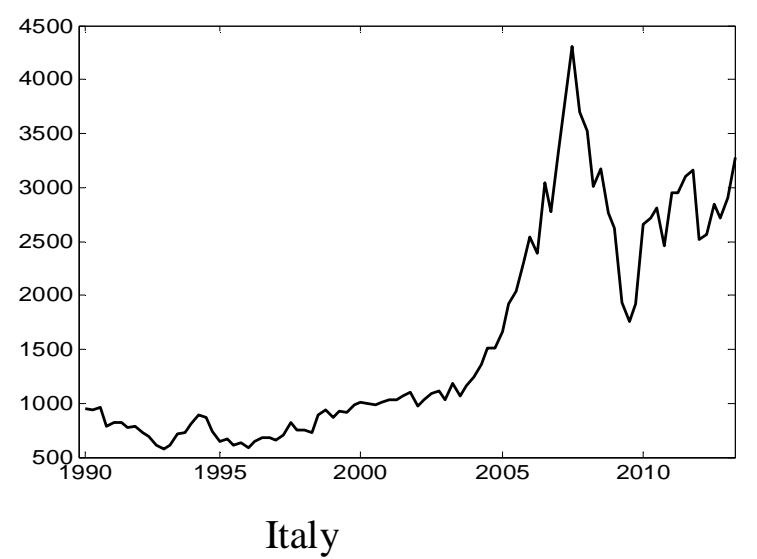

Belgium

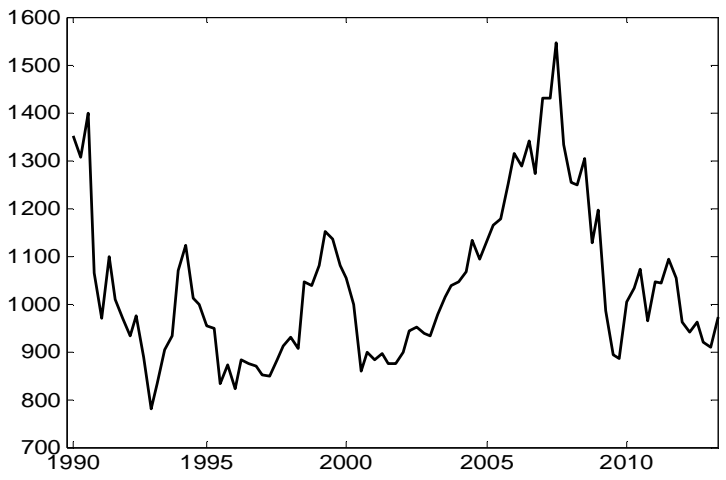

Finland

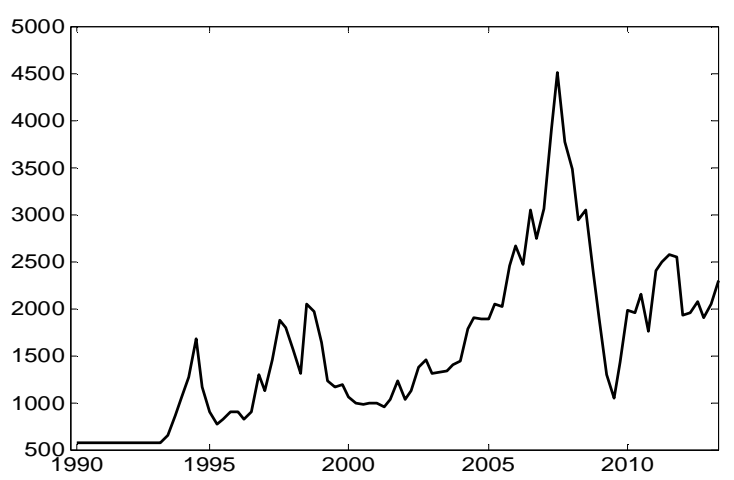

Germany

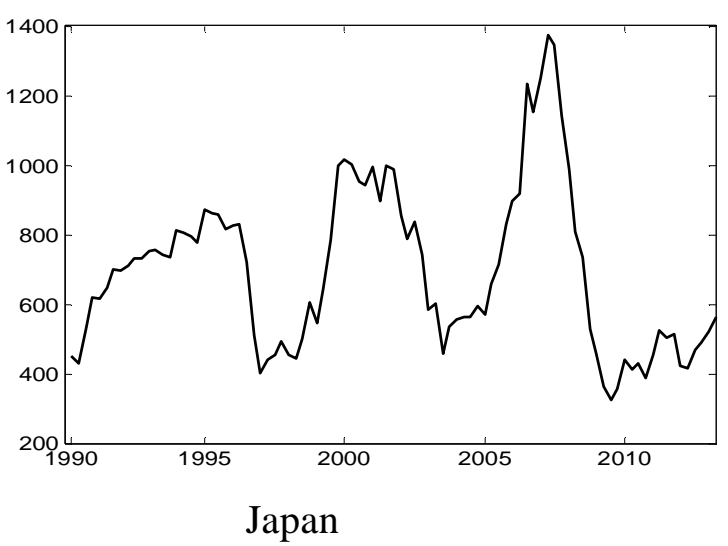




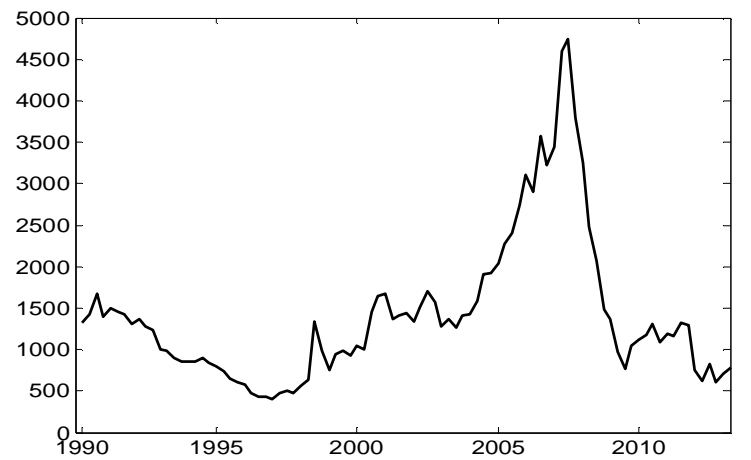

The Netherlands

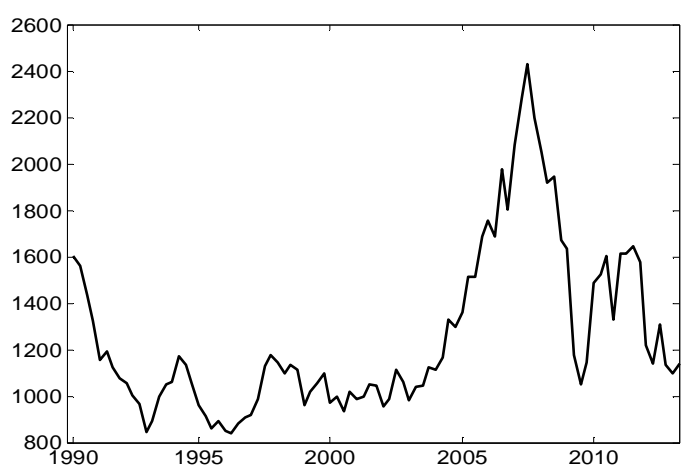

Sweden

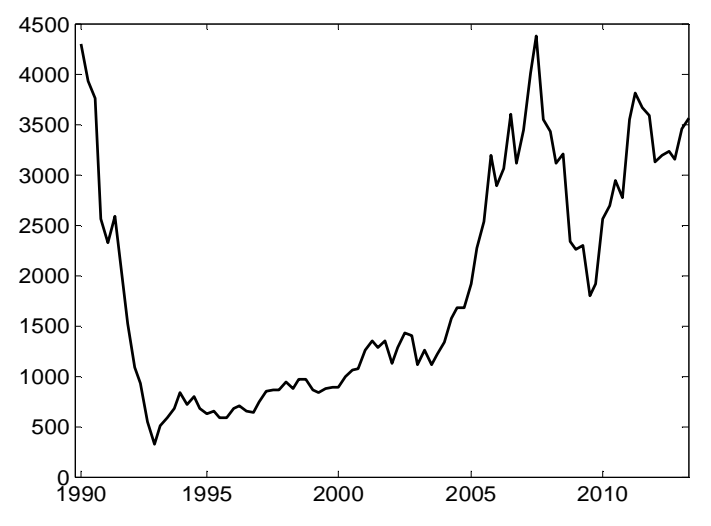

UK

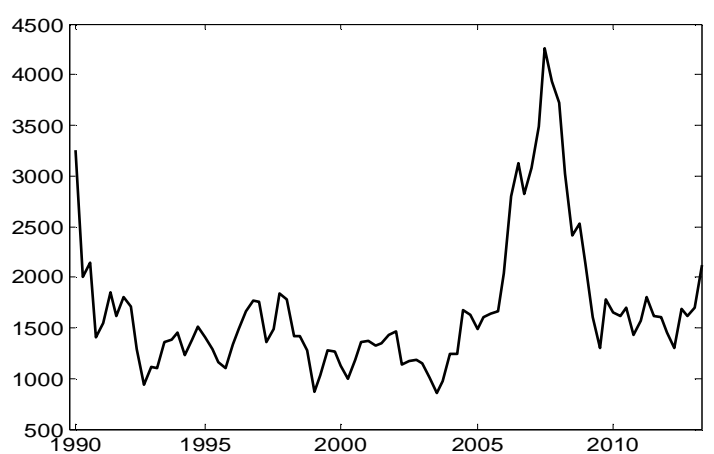

Spain

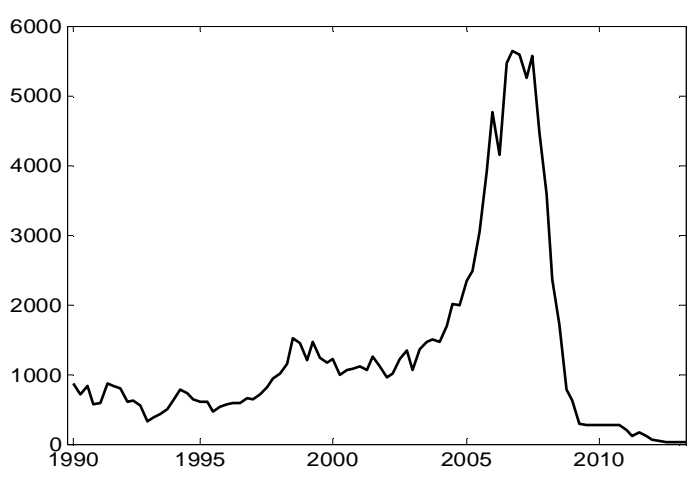

Switzerland

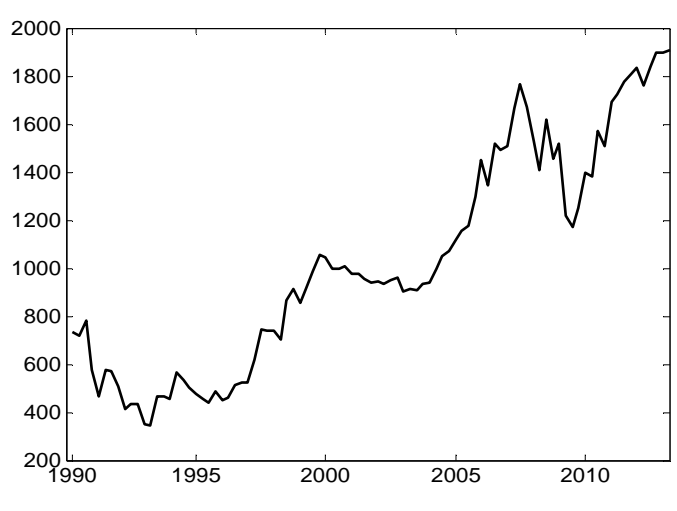

US 

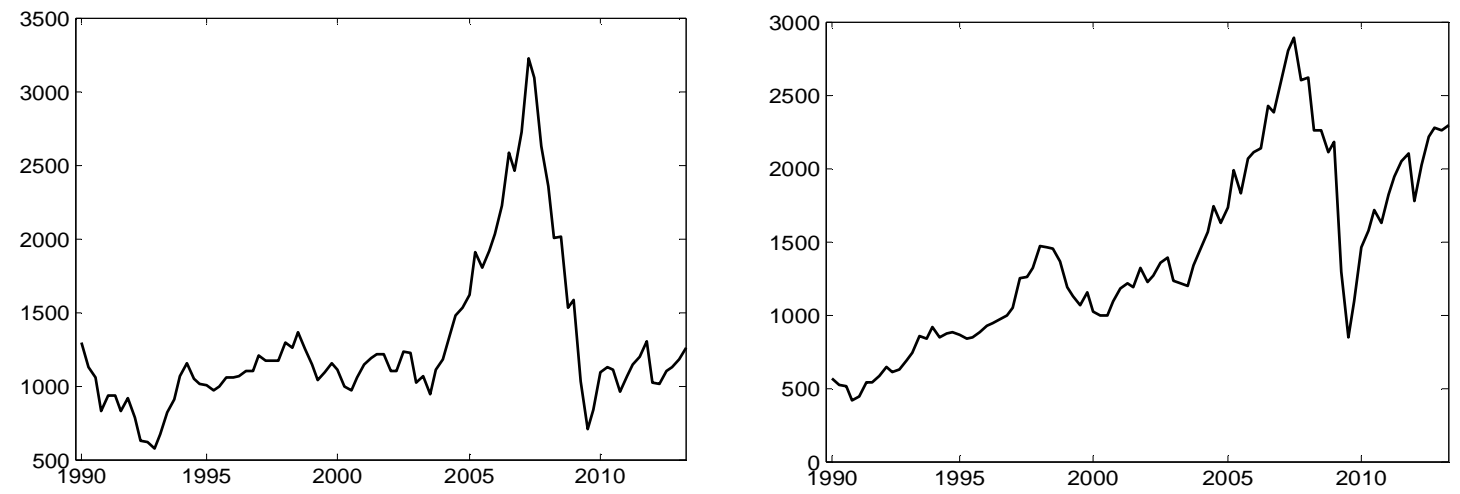
Exhibit 4: Average FDI and bank flows of Germany, Japan, UK, and US from 1990 to 2012

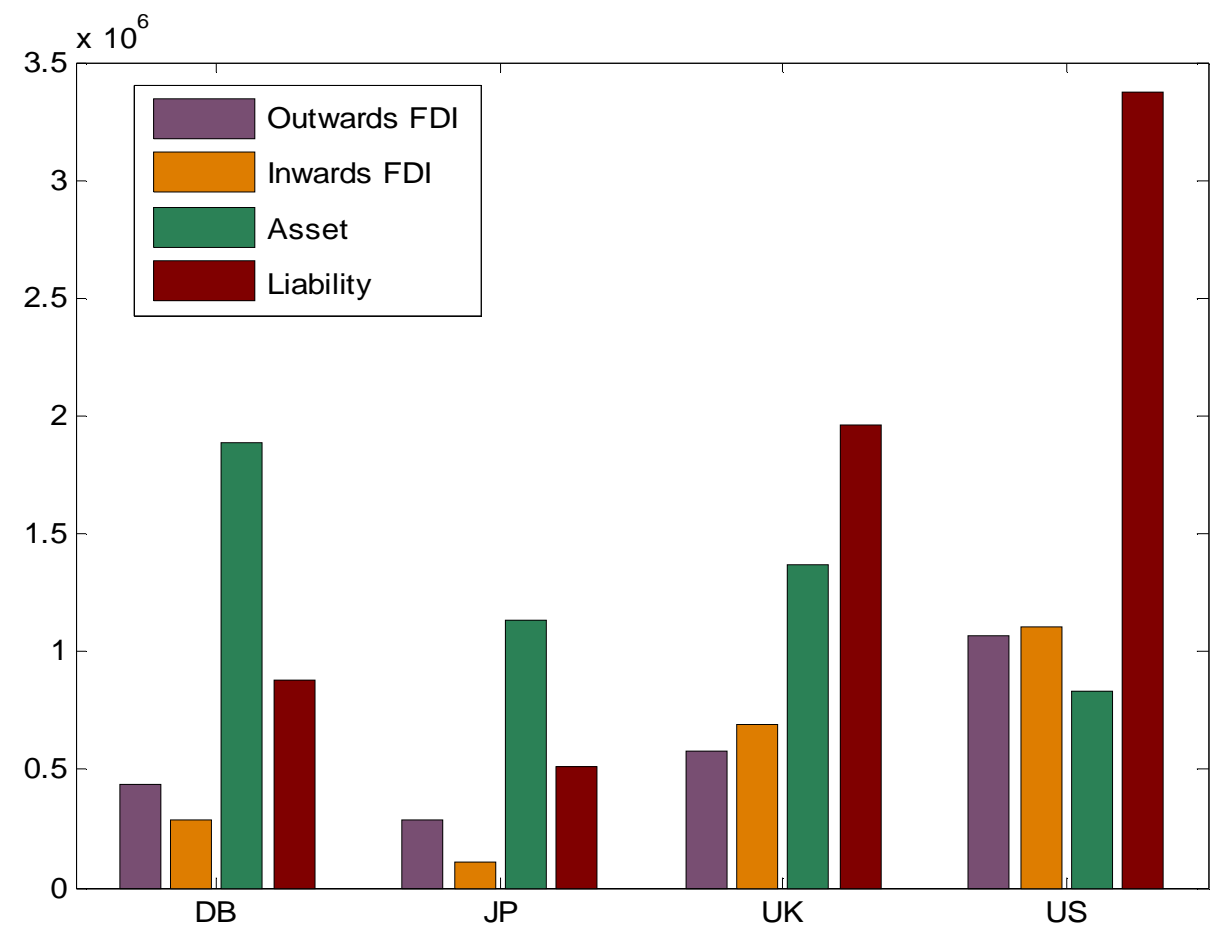

Note: Millions of US dollars. FDI is divided into outwards and inwards FDI and bank flows are divided into assets (claims) and liabilities of domestic banks with foreign banks. 
Exhibit 5: Goodness of fit of each model compared with a model using a randomly generated weight matrix

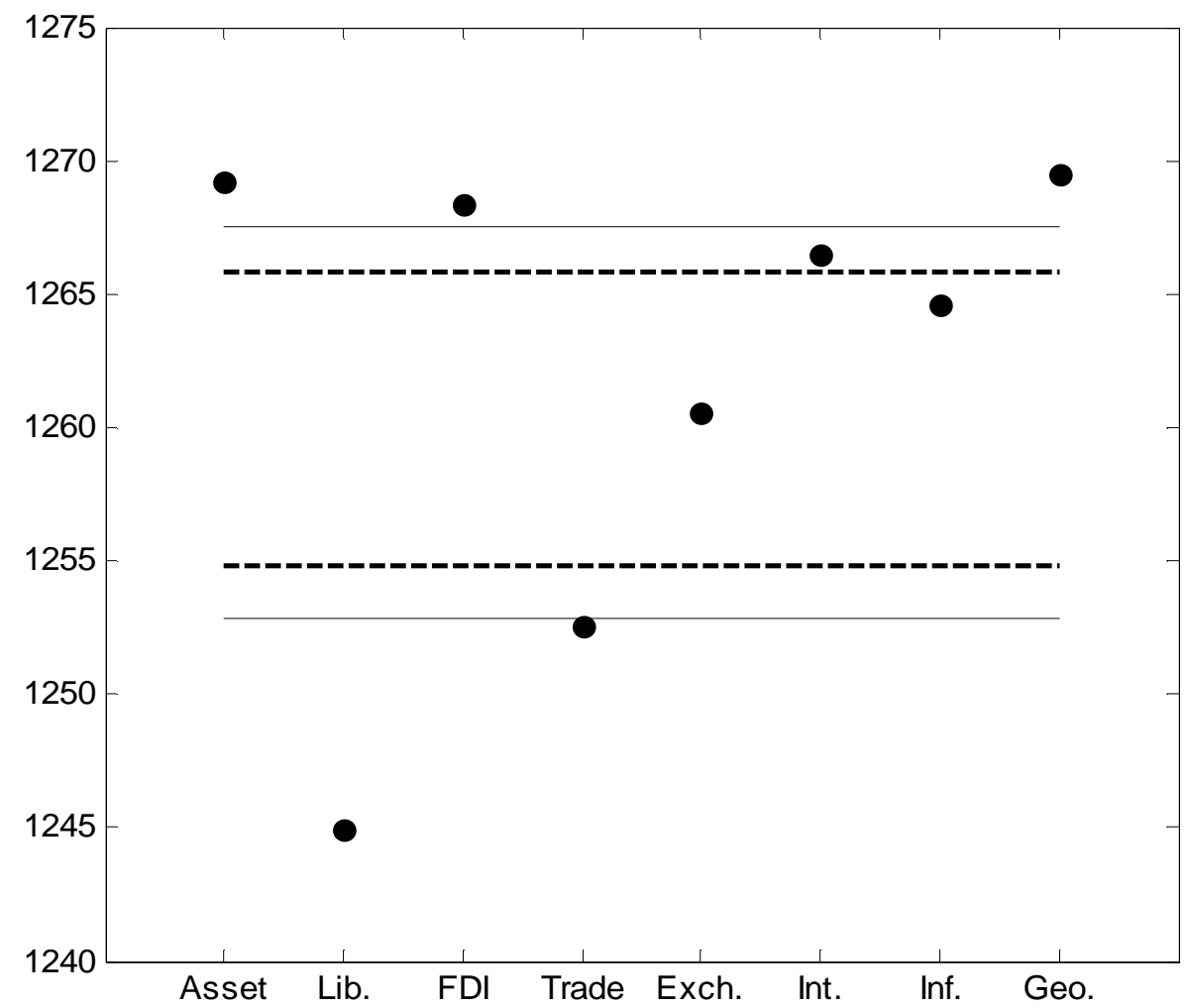

Note: This exhibit shows the log-likelihood value of the estimated models compared with the goodness of fit of a model based on 200 randomly generated weight matrices. The point denotes the goodness of fit of the models in Exhibit 1. The models are estimated as $Y_{N, t}=\rho W_{N, t} Y_{N, t}+\varphi Y_{N, t-1}+\delta W_{N, t-1} Y_{N, t-1}+X_{N, t} \beta+W_{N, t} X_{N, t} \lambda+Z_{t} \gamma+D_{N} \alpha+e_{N, t}$.

The solid line shows the $99.5 \%$ and $0.5 \%$ quantile of the log-likelihood value based on a model with 200 randomly generated weight matrices. The dotted line shows the $97.5 \%$ and $2.5 \%$ quantile. Models above the upper dotted or solid line perform show the best performance. 
Exhibit 6: Average immediate impact of a country-specific shock to the remaining countries before the GFC

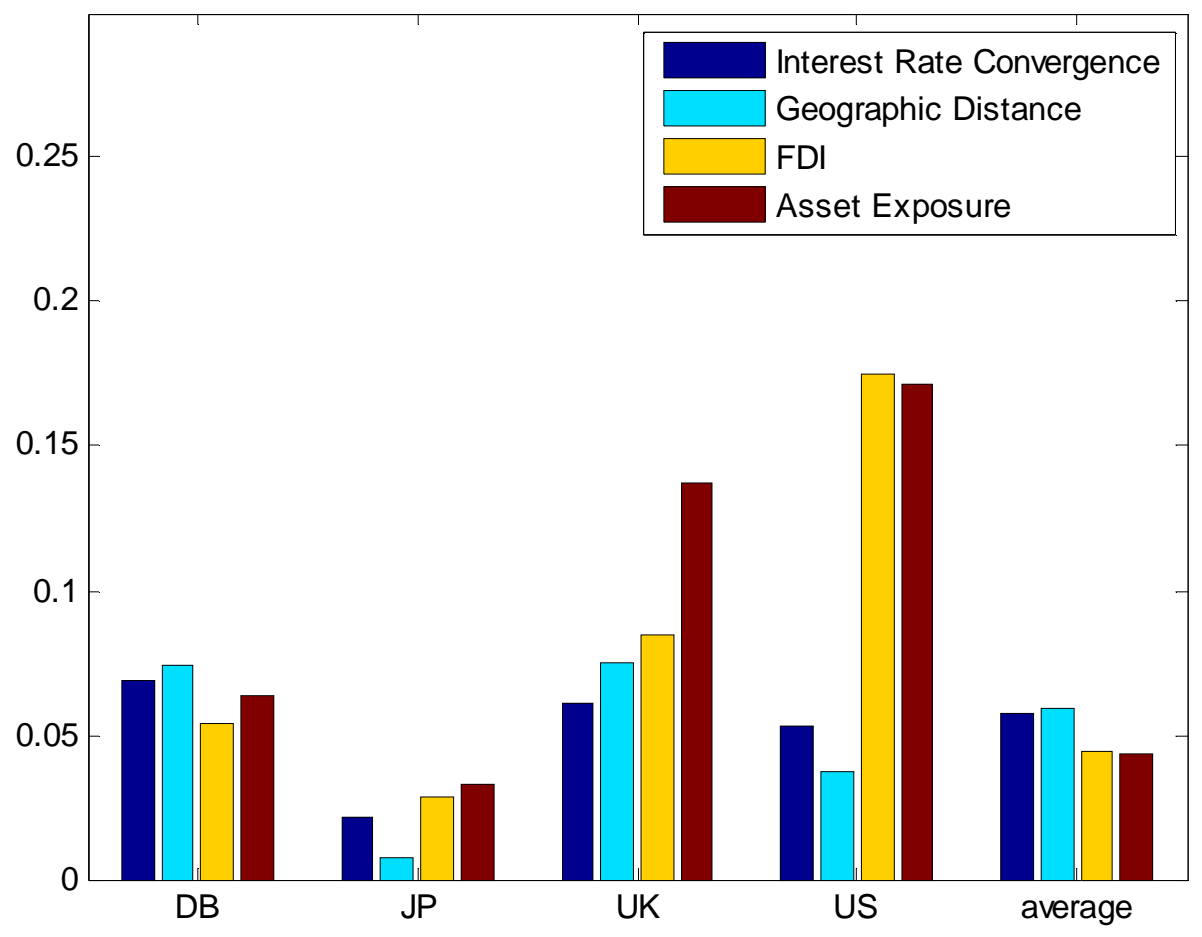


Exhibit 7: Average immediate impact of a country-specific shock to the remaining countries during the GFC

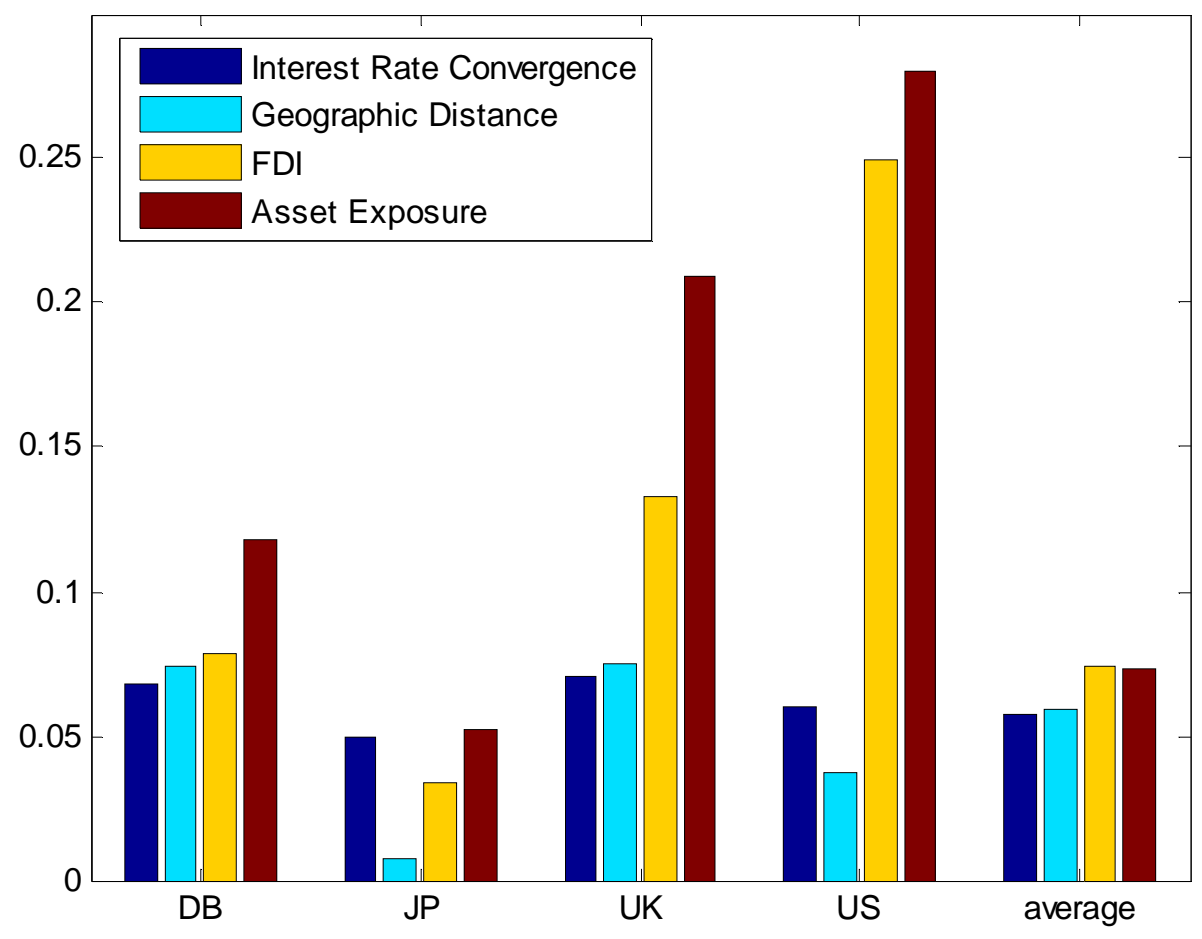




\section{References}

Allen, F., T. Beck, E. Carletti, P. R. Lane, D. Schoenmaker, and W. Wagner. Cross-border banking in Europe: Implications for financial stability and macroeconomic policies. CEPR Report, 2011.

Ambrose, B. W., D. W. Lee, and J. Peek. Comovement after joining an index: Spillovers of nonfundamental effects. Real Estate Economics, 2007, 35, 57-90.

Anselin, L. Spatial econometrics. In: Mills, T.C., Patterson, K. (Eds.), Palgrave Handbook of Econometrics, Econometric Theory, vol. 1. Basingstoke: Palgrave Macmillan, 2006, 901-969.

Asgharian, H. and C. Bengtsson. Jump spillover in international equity markets. Journal of Financial Econometrics, 2006, 4, 167-203.

Asgharian, H., W. Hess, and L. Liu. A spatial analysis of international stock market linkages. Journal of Banking \& Finance, 2013, 37, 4738-4754.

Asgharian, H. and M. Nossman. Risk contagion among international stock markets. Journal of International Money and Finance, 2011, 28, 22-38.

Beine, M., A. Cosma, and R. Vermeulen. The dark side of global integration: Increasing tail dependence. Journal of Banking and Finance, 2010, 34, 184-192.

Bodart, V. and P. Reding. Exchange rate regime, volatility and international correlations of bond and stock markets. Journal of International Money and Finance, 1999, 18, 133-151.

Bruno, V. and H. S. Shin. Cross-border banking and global liquidity. Working paper, Princeton University, 2014.

Cooper, I. and E. Kaplanis. Home bias in equity portfolios, inflation hedging, and international capital market equilibrium. Review of Financial Studies, 1994, 7, 45-60.

Ely, D. P. and K. J. Robinson. Are stocks a hedge against inflation? International evidence using a long-run approach. Journal of International Money and Finance, 1997, 16, 141-167.

Fazio, G. Extreme interdependence and extreme contagion between emerging markets. Journal of International Money and Finance, 2007, 26, 1261-1291. 
Fingleton, B. Equilibrium and economic growth spatial econometric models and simulations. Journal of Regional Science, 2001, 41(1), 117-141.

Fingleton, B. A generalized method of moments estimator for a spatial model with moving average errors, with application to real estate prices. Empirical Economics, 2008, 34(1), 35-57.

Flavin, T. J., M. J. Hurley, and F. Rousseau. Explaining stock market correlation: A gravity model approach. The Manchester School Supplement, 2002, 87-106.

Glascock, J., C. Lu, and R. So. Further evidence on the integration of REIT, bond and stock returns. Journal of Real Estate Finance and Economics, 2000, 20, 177-194.

Haining, R. Spatial Data Analysis: Theory and Practice. Cambridge: Cambridge University Press, 2003.

Hardouvelis, G., D. Malliaropulos, and R. Priestley. EMU and European stock market integration. Journal of Business, 2006, 79, 365-392.

Heritage. Trade Freedom. 2016. http://www.heritage.org/index/trade-freedom, last update 23.08.2016.

Hoesli, M., C. Lizieri, and B. MacGregor. The inflation hedging characteristics of US and UK investments: A multi-factor error correction approach. The Journal of Real Estate Finance and Economics, 2008, 36(2), 183-206.

Johnson, R. and L. Soenen. Asian economic integration and stock market comovement. The Journal of Financial Research, 2002, 25(1), 141-157.

Karolyi, G. A. and R. M. Stulz. Why do markets move together? An investigation of US-Japan stock return co-movements. Journal of Finance, 1996, 51, 951-986.

Marston, R. C. International Financial Integration: A Study of Interest Differentials between the Major Industrial Countries. Cambridge University Press, 1997.

McGuire, P. and N. Tarashev. Global monitoring with the BIS international banking statistics. In: Bank for International Settlements (Ed.), Research on Global Financial Stability: The Use of BIS 
International Financial Statistics 29, 2007, 176-204.

Miao, H., S. Ramchander, and M. C. Simpson. Return and volatility transmission in U.S. housing markets. Real Estate Economics, 2011, 39(4), 701-741.

Milcheva, S. Cross-country effects of regulatory capital arbitrage. Journal of Banking and Finance, 2013, 37, 5329-5345.

Milcheva, S. and Zhu, B. Bank integration and comovements across housing markets. Journal of Banking \& Finance, 2015, in press.

LeSage, J. and R. K. Pace. Introduction to Spatial Econometrics. Boca Raton, FL: Chapman \& Hall/ CRC, 2009.

Orlov, A. G. A cospectral analysis of exchange rate comovements during Asian financial crisis. Journal of International Financial Markets, Institutions \& Money, 2009, 19, 742-758.

Pesaran, M. H. and Y. Shin. Generalized impulse response analysis in linear multivariate models. Economic Letters, 1998, 58(1), 17-29.

Portes, R. and H. Rey. The determinants of cross-border equity flows. Journal of International Economics, 2005, 65, 269-296.

Simon, S. and W. L. Ng. The effect of real estate downturn on the link between REITs and the stock market. Journal of Real Estate Portfolio Management, 2009, 15(3), 211-219.

Van Dijk, D., T. Terasvirta, and P. H. Franses. Smooth transition autoregressive models - A survey of recent developments. Econometric Review, 2002, 21(1), 1-47.

Wälti, S. Stock market synchronization and monetary integration. Journal of International Money and Finance, 2010, 30, 96-110.

Zhu, B., R. Fuess, and N. Rottke. Spatial linkages in returns and volatilities among US regional housing markets. Real Estate Economics, 2013, 41 (1), 29-64. 